PROF. PETER COWAN (Orcid ID : 0000-0001-9016-4954)

3

4

Article type : Brief Communication

6

8 Pig endothelial protein C receptor is functionally compatible with the human protein C pathway

10 Evelyn J. Salvaris ${ }^{1^{*}}$, Christopher J. Moran ${ }^{1,2^{*}}$, Jean Christian Roussel ${ }^{1,3}$, Nella

11 Fisicaro ${ }^{1}$, Simon C. Robson ${ }^{4}$, Peter J. Cowan ${ }^{1,5}$

${ }^{1}$ Immunology Research Centre, St. Vincent's Hospital Melbourne, Victoria, Australia

${ }^{2}$ Current address: Department of Anaesthesia, Royal Women's Hospital, Melbourne,

Victoria, Australia

${ }^{3}$ Current address: l'institut du thorax, CHU Nantes, Nantes, France

${ }^{4}$ Beth Israel Deaconess Medical Center, Harvard Medical School, Boston, MA, USA

${ }^{5}$ Department of Medicine, University of Melbourne, Melbourne, Victoria, Australia

* These authors contributed equally to this study.

Running head: Pig EPCR is compatible with human TBM

Correspondence address:

\title{
Peter Cowan
}

This is the author manuscript accepted for publication and has undergone full peer review but has not been through the copyediting, typesetting, pagination and proofreading process, which may lead to differences between this version and the Version of Record. Please cite this article as doi: $10.1111 /$ XEN.12557

This article is protected by copyright. All rights reserved 
1 Immunology Research Centre, St. Vincent's Hospital Melbourne

PO Box 2900, Fitzroy 3065, Victoria, Australia

Tel: +61 39231 3140; Fax: +61 39231 3151; E-Mail: peter.cowan@svha.org.au

Word count: abstract 276; text (including abstract) 2363

\section{Abstract}

-

Background: Endothelial protein C receptor (EPCR) plays an anticoagulant and anti-inflammatory role by promoting the activation of protein $\mathrm{C}$ by thrombin bound to thrombomodulin (TBM). Incompatibility between pig TBM and human/primate thrombin is thought to contribute to dysregulated coagulation in pig-to-primate organ xenografts, and expression of human TBM (hTBM) in pigs has shown benefit in preclinical models. However, it is not known whether there are incompatibilities - or molecular barriers -- between endogenous pig EPCR (pEPCR) and transgenically expressed human TBM.

Aim: To clone and express pEPCR, and determine its function in the human protein C pathway in vitro.

Methods: pEPCR cDNA was generated from pig lung RNA by RT-PCR. Primate COS-7 transfectants expressing various combinations of human and pig TBM and EPCR were incubated with human thrombin and human protein $\mathrm{C}$, and tested for TBM co-factor activity.

Results: The predicted protein sequence of pEPCR shared $72.3 \%$ amino acid sequence identity with hEPCR, and residues critical for protein $C$ binding were conserved. COS-7 cells transfected with hEPCR, pEPCR or vector showed minimal TBM cofactor activity $(0.13 \pm 0.04,0.13 \pm 0.02$ and $0.14 \pm 0.06 \mathrm{U}$, respectively). The cofactor activity of hTBM-transfected cells $(1.18 \pm 0.29 \mathrm{U})$ was 8-fold higher than vector-transfected cells $(p=0.004)$ and further increased 4-fold and 3-fold by cotransfection with hEPCR $(5.01 \pm 1.12 \mathrm{U}, \mathrm{p}=0.004)$ or $\mathrm{pEPCR}(3.73 \pm 0.65 \mathrm{U}, \mathrm{p}=$ 0.003), respectively.

Conclusions: Our data show that PEPCR is largely compatible with the human TBM/thrombin complex, when expressed on COS-7 cells in vitro, promoting the activation of human protein $C$. These findings suggest that endogenous pEPCR will enhance the activity of transgenic hTBM in the xenograft setting. 
2 Keywords

3 Xenotransplantation, thrombomodulin, endothelial protein C receptor, protein C

4 pathway, coagulation

5 Abbreviations used

6 APC - activated protein $\mathrm{C}$

7 EPCR endothelial protein C receptor

8 FITC fluorescein isothiocyanate

$9 \quad$ GTKO $\quad \alpha 1,3-$ galactosyltransferase gene-knockout

$10 \mathrm{~h}$ human

11 MFI mean fluorescence intensity

$12 \mathrm{p}$ pig

13 PAEC porcine aortic endothelial cells

14 RACE rapid amplification of cDNA ends

15 RT-PCR reverse transcription - polymerase chain reaction

16 TBM thrombomodulin

\section{Authorship statement}

18 E.J.S. participated in the research design, performance of the research, data 19 analysis, writing and critical revision of the manuscript.

20 C.J.M. and J.C.R participated in the research design, performance of the research, 21 data analysis, and critical revision of the manuscript.

22 N.F. participated in the performance of the research, data analysis, and critical 23 revision of the manuscript.

24 S.C.R. participated in the research concept, design, and critical revision of the 25 manuscript. 
1 P.J.C. secured funding and participated in the research concept and design, data 2 analysis, and writing of the manuscript, and carried the main responsibility for the 3 study.

4

\section{Acknowledgements}

6 This study was supported by a grant from the National Health \& Medical Research

7 Council of Australia (558408).

\section{Introduction}

Xenotransplantation is a possible solution to the limited supply of human donor organs available for transplantation. The pig is a suitable donor due to its physiological and morphological similarity with humans (1), and significant progress has been made by genetically modifying donor pigs to prevent rejection of porcine xenografts (2). Dysregulated coagulation has frequently been a barrier to long-term survival in pig-to-nonhuman primate preclinical models (3). Therefore, one of the goals of the genetic approach is to overcome cross-species molecular incompatibilities affecting the regulation of coagulation, notably the failure of pig thrombomodulin (pTBM) to interact efficiently with human thrombin (4-6).

The protein $C$ pathway is a key regulator of coagulation and inflammation in the microvasculature. The integral endothelial protein TBM binds circulating thrombin, blocking its procoagulant activity and converting it to an anticoagulant by changing its substrate specificity from prothrombin to protein $C$. Activated protein C (APC) inhibits coagulation by irreversibly inactivating factors Va and VIIla (7). TBM thus acts as a cofactor for thrombin's activation of protein C. A second transmembraneanchored molecule, endothelial protein $C$ receptor (EPCR), significantly enhances TBM cofactor activity by binding protein $C$ and presenting it to the TBM/thrombin complex (8). EPCR also has TBM-independent anti-inflammatory, anti-apoptotic and cytoprotective effects via binding of APC and cleavage of PAR-1 $(9,10)$.

Our in vitro studies have shown that PTBM binds human thrombin but is a poor cofactor for the subsequent activation of human protein $C$ (6). We have also demonstrated that overexpression of hTBM protects against transplant-related injury 
1 in a transgenic mouse model (11). Several groups have generated hTBM-expressing

2 transgenic pigs, and although the results from preclinical models are not yet conclusive, they suggest that hTBM protects against the development of dysregulated coagulation (12-15). However, in the context of a porcine xenograft, it is not known whether endogenous pig EPCR (pEPCR) will be functionally compatible with hTBM expressed by transgenic pig endothelial cells.

To address this question, we cloned pEPCR and expressed it in transfected cells to examine its ability to enhance hTBM cofactor activity for human thrombin-mediated 
1 Australia), hTBM (Clone IA4, WEHI), or hEPCR (rat anti-mouse hEPCR Clone RCR-

2 252, BD Biosciences). The anti-hTBM and anti-hEPCR mAbs did not cross-react with pig (data not shown).

4

\section{Thrombomodulin cofactor activity assay}

TBM cofactor activity was determined essentially as previously described (6). $48 \mathrm{hrs}$ after transfection, $5 \times 10^{4}$ cells were incubated for $30 \mathrm{~min}$ with $0.1 \mathrm{U} / \mathrm{ml}$ human thrombin and $150 \mathrm{nM}$ human protein C (Merck-Millipore, Bayswater, Victoria, Australia) in a $100 \mu \mathrm{l}$ reaction at $37^{\circ} \mathrm{C}$. The reaction was terminated by addition of 4 $\mu \mathrm{l} 2 \mathrm{U} / \mathrm{ml}$ hirudin (Merck), and the concentration of APC generated (nM) was measured using the Spectrozyme PCa chromogenic substrate (Vital Diagnostica, Castle Hill, New South Wales, Australia), by measuring absorbance at $405 \mathrm{~nm}$ using a FLUOStar Omega kinetic plate reader (BMG Labtech, Offenburg, Germany). Cofactor activity was calculated as Units, where $1 \mathrm{U}=1 \mathrm{nM} \mathrm{APC} / 5 \times 10^{5}$ cells $/ 30 \mathrm{~min}$. Data were corrected for transfection efficiency using the mean fluorescence intensity (MFI) of an aliquot of cells stained for hTBM and analyzed by flow cytometry.

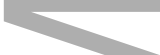

\section{Statistical analysis}

Results are presented as mean \pm standard error of the mean (SEM) of 5-7 independent experiments, performed in triplicate. Data were analyzed using unpaired Student t Test (2-tailed).

\section{Results}

\section{pEPCR and hEPCR are highly similar at the protein and gene levels}

Pig lung was used as a source of pEPCR RNA because the lung is an organ which is rich in endothelial cells. A 331-bp product was amplified by PCR of pig lung cDNA using a degenerate upstream primer (5'-TCTTCGAWGTGGCTGGTGAATGG-3') based on homology between human, bovine and mouse EPCR, and a downstream primer (5'-TTGCGGCCGCGGAGAGTAATTAACATCGC-3') specific for hEPCR. A product of the same size was generated when cDNA from the human endothelial cell 
1 line EAhy926 cDNA, but not from the immortalized pig aortic endothelial cell line

2 SVAP, was used. The failure to generate an EPCR product from SVAP cells was unlikely to be due to the quality of the SVAP cDNA, because pTBM could be readily amplified from the same preparation (data not shown).

The sequence of the pig lung PCR product was $87 \%$ identical to that of bovine EPCR, and was used to design specific primers for rapid amplification of DNA ends (RACE). This generated a $0.6 \mathrm{~kb} 3^{\prime}$ RACE product extending the pEPCR cDNA sequence to a polyA tail. Attempts to generate a 5' RACE product were unsuccessful. Instead, the $5^{\prime}$ sequence of pEPCR cDNA was extended by PCR using a primer for the $5^{\prime}$-untranslated region of hEPCR $\left(5^{\prime}-\right.$ CGAGCCAGGAACCCAGGT) and the hEPCR downstream primer listed above. The resulting $1.4 \mathrm{~kb}$ putative $\mathrm{pEPCR}$ cDNA sequence contained an open reading frame encoding a predicted 242-residue protein, including an 18-residue signal sequence (17), a 195-residue extracellular domain, a 23-residue transmembrane domain (identified using the program at www.cbs.dtu.dk/services/TMHMM), and a 6-residue class I/CD1 domain characteristic of hEPCR. The mature pEPCR protein was $72.3 \%$ identical to mature hEPCR (Fig. 2). In the critical protein C-binding MHC I/CD1 domain, identity was $73.7 \%$, increasing to $83.8 \%$ when conserved residues were included. Of 10 residues in hEPCR known to be essential for binding of human APC (18), marked by red asterisks in Fig. 2, 7 were identical and 3 were conserved in pEPCR. In addition, the $4 \mathrm{~N}$-linked glycosylation sites in hEPCR, which are not critical for protein $\mathrm{C}$ binding but may contribute to stability (18), were conserved in pEPCR.

Comparison of the pEPCR cDNA sequence with the porcine genome revealed 99.5\% identity with a region of chromosome 17 (sequence ID: NC_010459.5). The comparison indicated that the pEPCR gene spans $4.6 \mathrm{~kb}$ and contains 4 exons (>120 bp and approximately 250, 280 and 700 bp) separated by 3 introns of approximately $2.6 \mathrm{~kb}, 370 \mathrm{bp}$ and $240 \mathrm{bp}$. This structure is similar to that of the hEPCR gene on chromosome $20(19,20)$, with the exception that the second intron of hEPCR is larger (1217 bp). The pEPCR amino acid sequences predicted from the cDNA (Fig. 1) and the available genomic sequence were identical. 
pEPCR interacts with human TBM/thrombin to promote activation of human protein $C$ in vitro

COS-7 cells, which have negligible TBM cofactor activity (6), were transiently transfected with expression vectors for FLAG-tagged hTBM, hEPCR and pEPCR; alone or in combination. Flow cytometric analysis of hTBM-transfected cells using an hTBM-specific antibody showed strong expression of hTBM that was not significantly affected by co-transfection with hEPCR or pEPCR (Fig. 3). Expression of hEPCR was also comparable between experiments: the mean fluorescence intensity (MFI) for $\mathrm{hTBM} / \mathrm{hEPCR}$ was $221.5 \pm 36.9$ versus $47.0 \pm 3.6$ for vector-transfected cells (both $n=6$ ). Expression of $p E P C R$ was not measured due to the lack of a specific detection antibody.

48 hrs after transfection, cells were analyzed for TBM cofactor activity in the presence of human thrombin and human protein $\mathrm{C}$ using the Spectrozyme $\mathrm{PCa}$ chromogenic assay. As expected, cells transfected with vector, hEPCR or pEPCR alone, in the absence of hTBM, showed minimal cofactor activity $(0.14 \pm 0.06,0.13 \pm$ 0.04 and $0.13 \pm 0.02 \mathrm{U}$, respectively). Cofactor activity of cells transfected with pTBM was also minimal $(0.18 \pm 0.05 \mathrm{U}, \mathrm{p}=0.578$ vs vector-transfected $)$, as previously reported (6). Cofactor activity of hTBM-transfected cells $(1.18 \pm 0.29 \mathrm{U})$ was 8 -fold higher than that of vector-transfected cells $(p=0.004)$, and was increased a further 4-fold or 3-fold by co-transfection with hEPCR (5.01 $\pm 1.12 \mathrm{U}, p=0.004)$ or pEPCR $(3.73 \pm 0.65 \mathrm{U}, p=0.003)$, respectively (Fig. 4). We did not attempt to measure the anti-inflammatory and cytoprotective/anti-apoptotic activity of EPCR because these functions are dependent on PAR-1, which is not expressed in COS-7 cells (21).

\section{Discussion}

Transgenic expression of hTBM in donor pigs is aimed at preventing dysregulated coagulation by bypassing the molecular incompatibility between PTBM and human thrombin/protein C (3). Recent evidence suggests that hTBM expression improves vascular thromboregulation and thereby prolongs solid organ xenograft survival (13, 22). However, the cross-species compatibility of another important component of the 
1 protein C pathway, EPCR, has not previously been examined. We therefore asked 2 whether endogenous pEPCR would enhance the activity of hTBM in vitro as representative of the setting of a transgenic organ xenograft.

4 To address this question, we cloned pEPCR and compared its sequence and activity 5 to that of hEPCR. Interestingly, we were able to generate pEPCR cDNA from pig lung but not from a pig aortic endothelial cell line. This was somewhat surprising since EPCR appears to be preferentially expressed in large vessels, at least in humans (23), but may be explained by altered gene expression in cell lines compared to primary cells. The comparison of pig and human EPCR protein sequences revealed a high degree of homology. Notably, $83.8 \%$ of residues were identical or conserved in the MHC I/CD1 domain, which binds the Gla domain of protein C/APC (24). It was therefore unsurprising that co-expression of pEPCR with hTBM in transfected cells significantly increased the latter's cofactor activity, demonstrating that pEPCR facilitates activation of human protein $\mathrm{C}$ by the human TBM/thrombin complex in vitro. While the 3-fold increase was relatively modest, it was not significantly different to that achieved with co-expression of hEPCR (4-fold), which in turn was similar to that previously reported for hEPCR in vitro (approximately 5-fold) (8). Furthermore, a study in primates suggests that these in vitro measures considerably underestimate the in vivo impact of EPCR on TBM cofactor activity (25).

Nevertheless, while our data and those of others (13) suggest that there is no absolute need to co-express hEPCR with hTBM, it may still be beneficial. Analysis of sera from baboons which had rejected porcine cardiac xenografts revealed the presence of elicited antibodies directed against several porcine cell surface proteins including CD46, CD59 and EPCR (26). Failure to completely prevent the generation of these antibodies may contribute to a vicious cycle of inflammation and coagulation, but conceptually this could be nullified by transgenic expression of the human homologs of the porcine complement and coagulation regulators, if these were appropriately modified in a post-translational manner. Furthermore, although not specifically addressed here, supraphysiological expression of human EPCR may amplify its own TBM-independent cytoprotective effects.

\section{References}


1 1. Cooper DK, Gollackner B, Sachs DH. Will the pig solve the transplantation

2 backlog? Annu Rev Med. 2002;53:133-47.

3 2. Cowan PJ, Tector AJ. The Resurgence of Xenotransplantation. Am J

4 Transplant. 2017;17(10):2531-6.

5 3. Cowan PJ, Robson SC, d'Apice AJ. Controlling coagulation dysregulation in 6 xenotransplantation. Curr Opin Organ Transplant. 2011;16(2):214-21.

7 4. Siegel JB, Grey ST, Lesnikoski BA, Kopp CW, Soares M, Schulte am Esch J, 8 2nd, et al. Xenogeneic endothelial cells activate human prothrombin.

9 Transplantation. 1997;64(6):888-96.

5. Kopp CW, Grey ST, Siegel JB, McShea A, Vetr H, Wrighton CJ, et al.

Expression of human thrombomodulin cofactor activity in porcine endothelial cells. Transplantation. 1998;66(2):244-51. 6. Roussel JC, Moran CJ, Salvaris EJ, Nandurkar HH, d'Apice AJ, Cowan PJ. Pig thrombomodulin binds human thrombin but is a poor cofactor for activation of human protein C and TAFI. Am J Transplant. 2008;8(6):1101-12.

7. Esmon CT. The protein C pathway. Chest. 2003;124(3 Suppl):26S-32S.

8. Stearns-Kurosawa DJ, Kurosawa S, Mollica JS, Ferrell GL, Esmon CT. The endothelial cell protein $\mathrm{C}$ receptor augments protein $\mathrm{C}$ activation by the thrombinthrombomodulin complex. Proc Natl Acad Sci U S A. 1996;93(19):10212-6. 9. Jackson C, Whitmont K, Tritton S, March L, Sambrook P, Xue M. New therapeutic applications for the anticoagulant, activated protein C. Expert Opin Biol Ther. 2008;8(8):1109-22.

10. Bae JS, Yang L, Rezaie AR. Lipid raft localization regulates the cleavage specificity of protease activated receptor 1 in endothelial cells. J Thromb Haemost. 2008;6(6):954-61.

11. Crikis S, Zhang XM, Dezfouli S, Dwyer KM, Murray-Segal LM, Salvaris E, et al. Anti-inflammatory and anticoagulant effects of transgenic expression of human thrombomodulin in mice. Am J Transplant. 2010;10(2):242-50.

12. Wuensch A, Baehr A, Bongoni AK, Kemter E, Blutke A, Baars W, et al. Regulatory sequences of the porcine THBD gene facilitate endothelial-specific expression of bioactive human thrombomodulin in single- and multitransgenic pigs. Transplantation. 2014;97(2):138-47. 13. Mohiuddin MM, Singh AK, Corcoran PC, Thomas lii ML, Clark T, Lewis BG, et al. Chimeric 2C10R4 anti-CD40 antibody therapy is critical for long-term survival of 
1 GTKO.hCD46.hTBM pig-to-primate cardiac xenograft. Nature communications.

$2 \quad 2016 ; 7: 11138$.

3 14. Iwase H, Ekser B, Satyananda V, Bhama J, Hara H, Ezzelarab M, et al. Pig-

4 to-baboon heterotopic heart transplantation - exploratory preliminary experience with

5 pigs transgenic for human thrombomodulin and comparison of three costimulation

6 blockade-based regimens. Xenotransplantation. 2015;22(3):211-20.

7 15. Langin M, Mayr T, Reichart B, Michel S, Buchholz S, Guethoff S, et al.

8 Consistent success in life-supporting porcine cardiac xenotransplantation. Nature.

9 2018;564(7736):430-3.

16. Godwin JW, d'Apice AJ, Cowan PJ. Characterization of pig intercellular adhesion molecule-2 and its interaction with human LFA-1. Am J Transplant. 2004;4(4):515-25. 17. Petersen TN, Brunak S, von Heijne G, Nielsen H. SignalP 4.0: discriminating signal peptides from transmembrane regions. Nat Methods. 2011;8(10):785-6. 18. Liaw PC, Mather T, Oganesyan N, Ferrell GL, Esmon CT. Identification of the protein $\mathrm{C}$ /activated protein $\mathrm{C}$ binding sites on the endothelial cell protein $\mathrm{C}$ receptor. Implications for a novel mode of ligand recognition by a major histocompatibility complex class 1-type receptor. J Biol Chem. 2001;276(11):8364-70.

19. Simmonds RE, Lane DA. Structural and functional implications of the intron/exon organization of the human endothelial cell protein C/activated protein $\mathrm{C}$ complex alpha1 and alpha2 domains. Blood. 1999;94(2):632-41.

20. Hayashi T, Nakamura H, Okada A, Takebayashi S, Wakita T, Yuasa H, et al. Organization and chromosomal localization of the human endothelial protein $\mathrm{C}$ receptor gene. Gene. 1999;238(2):367-73.

21. Blackhart BD, Ruslim-Litrus L, Lu CC, Alves VL, Teng W, Scarborough RM, et al. Extracellular mutations of protease-activated receptor-1 result in differential activation by thrombin and thrombin receptor agonist peptide. Mol Pharmacol. 2000;58(6):1178-87.

22. Wang L, Cooper DKC, Burdorf L, Wang Y, Iwase H. Overcoming Coagulation Dysregulation in Pig Solid Organ Transplantation in Nonhuman Primates: Recent Progress. Transplantation. 2018;102(7):1050-8. 
1 23. Laszik Z, Mitro A, Taylor FB, Jr., Ferrell G, Esmon CT. Human protein C

2 receptor is present primarily on endothelium of large blood vessels: implications for

3 the control of the protein C pathway. Circulation. 1997;96(10):3633-40.

4 24. Regan LM, Mollica JS, Rezaie AR, Esmon CT. The interaction between the

5 endothelial cell protein $\mathrm{C}$ receptor and protein $\mathrm{C}$ is dictated by the gamma-

6 carboxyglutamic acid domain of protein C. J Biol Chem. 1997;272(42):26279-84.

7 25. Taylor FB, Jr., Peer GT, Lockhart MS, Ferrell G, Esmon CT. Endothelial cell

8 protein $\mathrm{C}$ receptor plays an important role in protein $\mathrm{C}$ activation in vivo. Blood.

9 2001;97(6):1685-8.

26. Byrne GW, Stalboerger PG, Du Z, Davis TR, McGregor CG. Identification of new carbohydrate and membrane protein antigens in cardiac xenotransplantation. Transplantation. 2011;91(3):287-92.

\section{Figure Legends}

Figure 1. cDNA and predicted amino acid sequence of pEPCR.

\section{Figure 2. Homology between the protein sequences of pig and human EPCR.}

Vertical bars and colons indicate identity and conservation of amino acid residues, respectively. Red asterisks denote hEPCR residues that have been shown to be essential for human APC binding (18). Other annotations are as described for Fig. 1.

\section{Figure 3. hTBM expression in transfected COS-7 cells.}

A) Flow cytometric profiles of COS-7 cells transiently transfected with hTBM \pm hEPCR or pEPCR, showing similar hTBM expression. B) Quantitation of hTBM expression averaged over 5-7 independent experiments, showing reproducible transfection efficiency. Vector and hTBM, n = 7; hTBM/pEPCR, $n=5 ;$ hTBM/hEPCR, $\mathrm{n}=6 . \mathrm{MFI}$ : mean fluorescence intensity. 
2 Figure 4. TBM cofactor activity of transfected COS-7 cells.

3 A) Cofactor activity for human thrombin-mediated activation of human protein $\mathrm{C}$, 4 assayed by Spectrozyme PCa. Cofactor activity was significantly increased by hTBM 5 expression, and further significantly increased by co-expression of hEPCR or 6 pEPCR. Vector, pTBM and hTBM: $n=7$; hTBM/pEPCR: $n=5 ;$ hTBM/hEPCR: $n=6$. $7 \quad$ B) Typical Spectrozyme PCa plots.

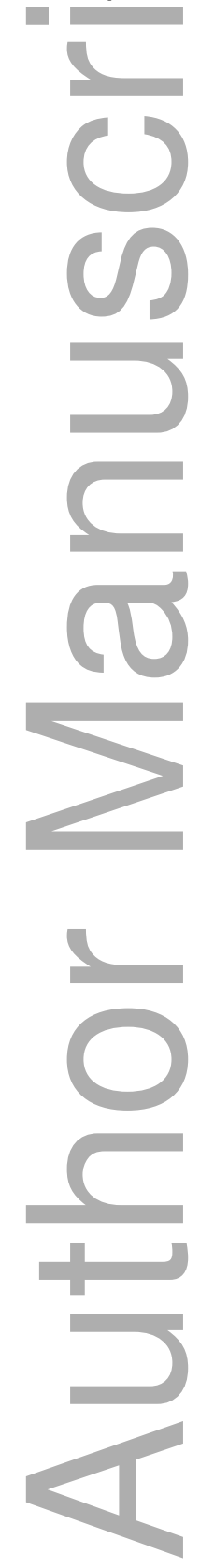




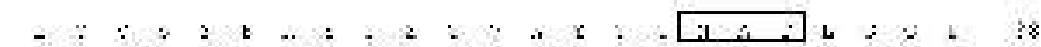

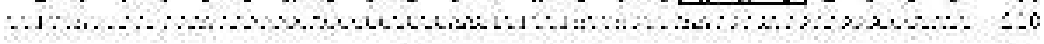

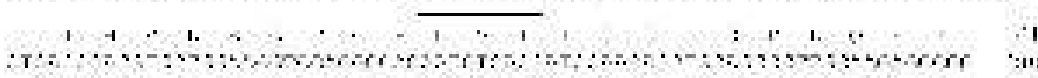

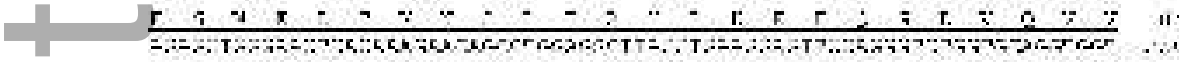

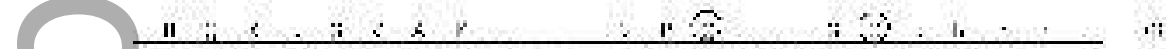

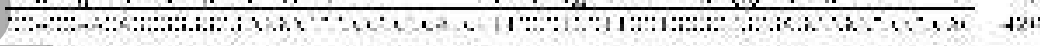

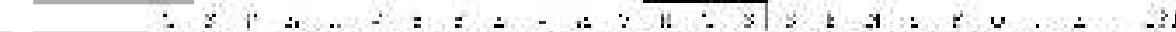

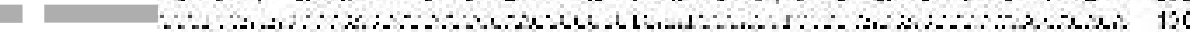

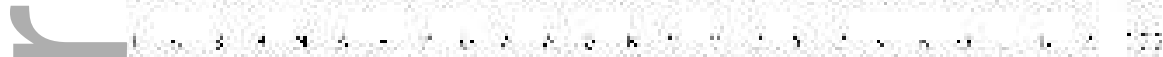

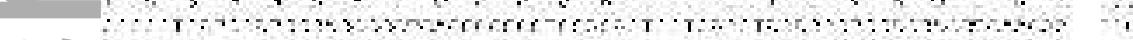

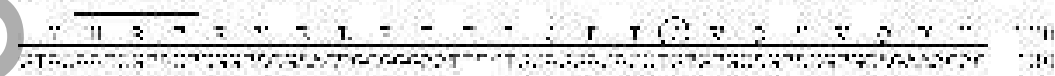

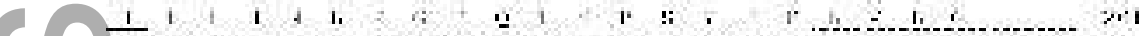

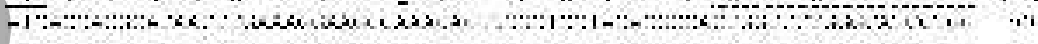

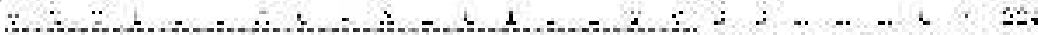

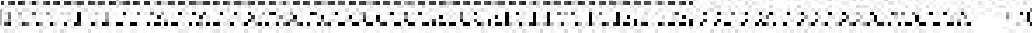

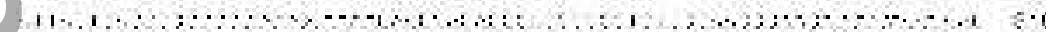

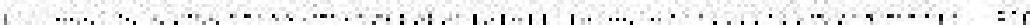
т:т:

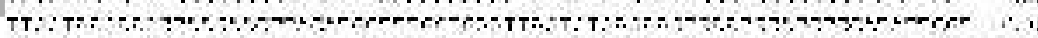

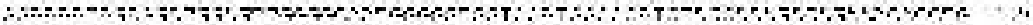

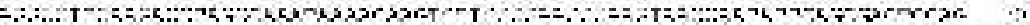

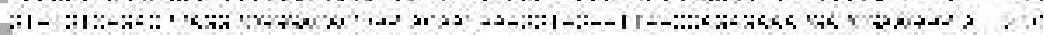

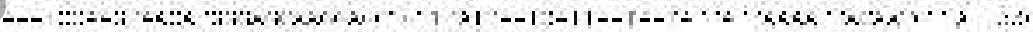

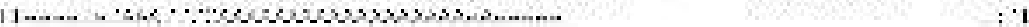
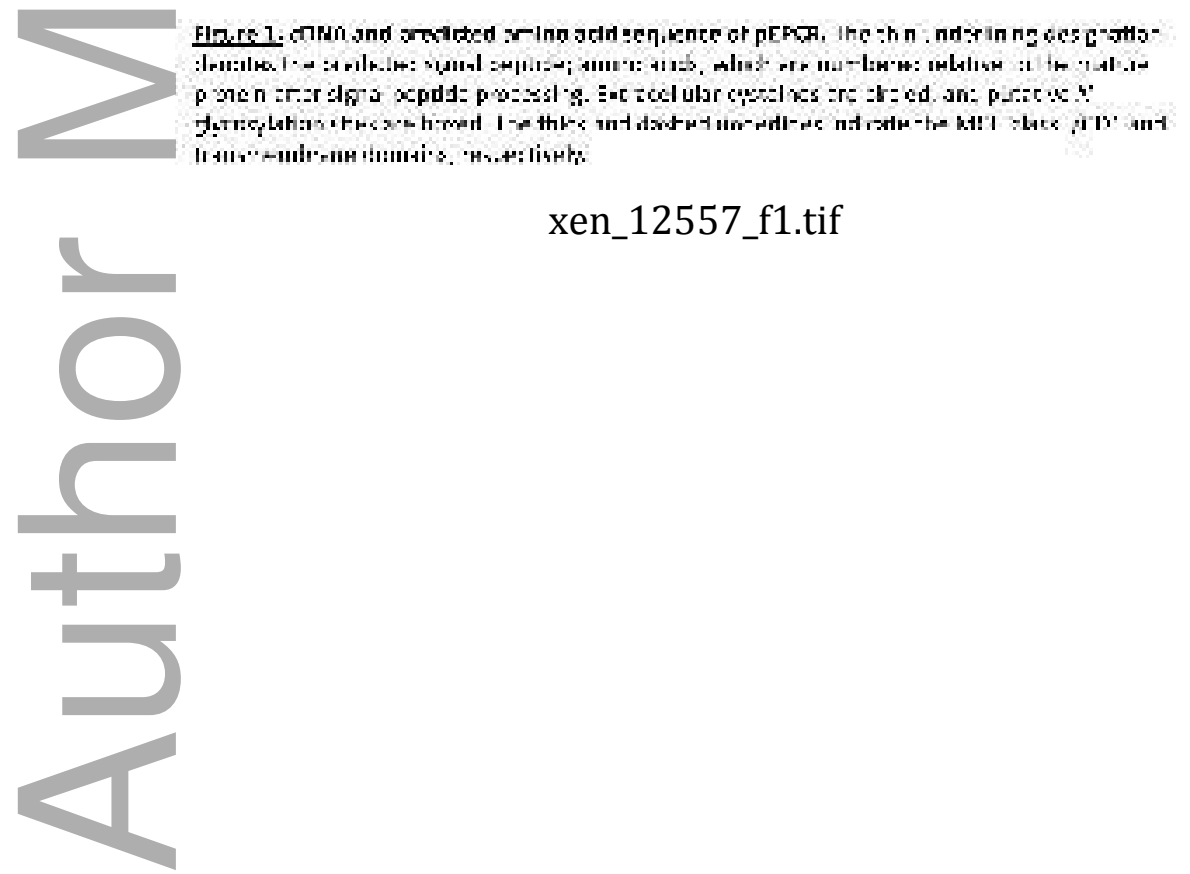

xen_12557_f1.tif 


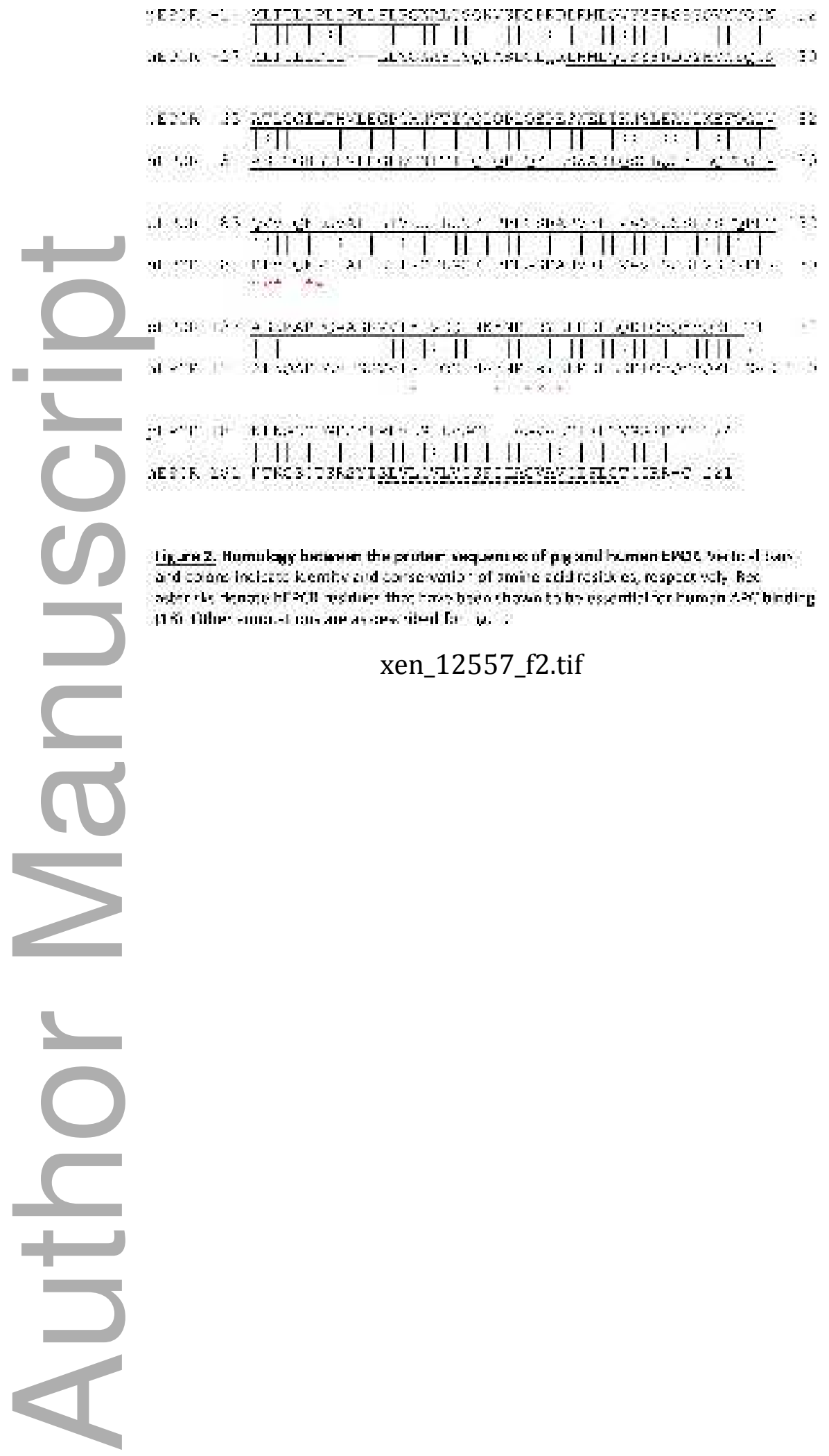

This article is protected by copyright. All rights reserved 


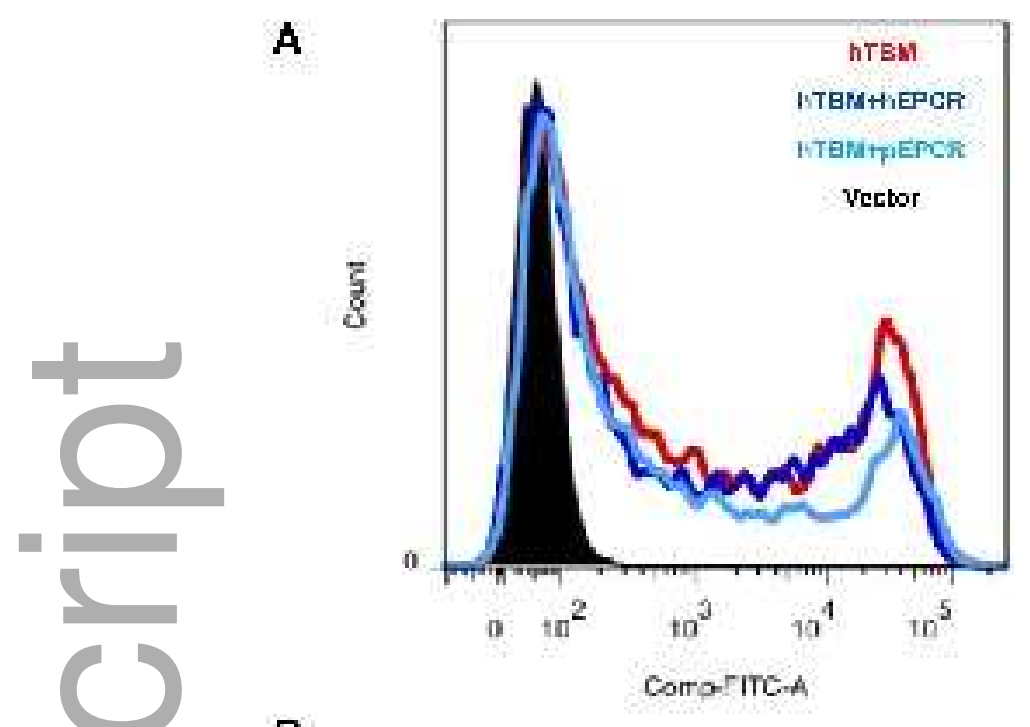

B

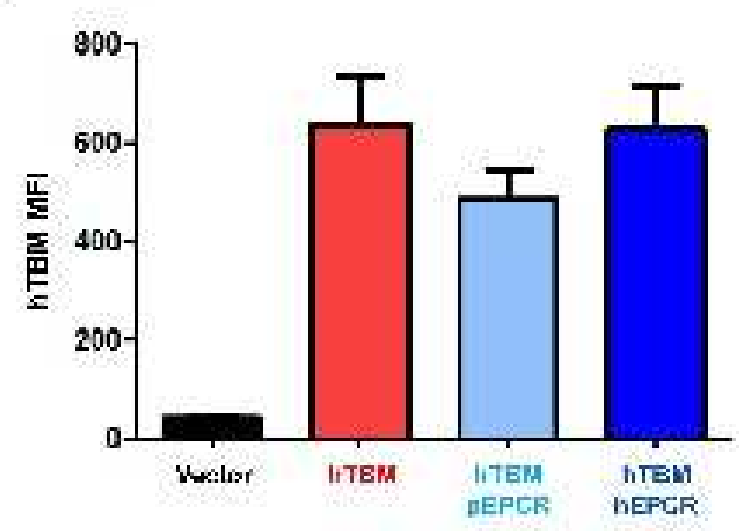

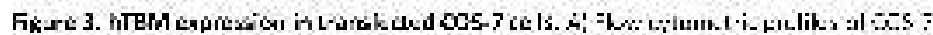

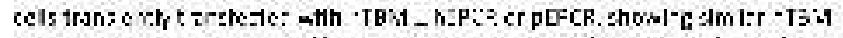

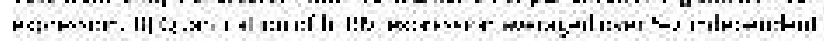

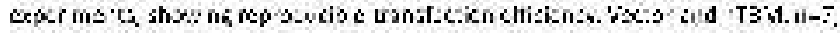

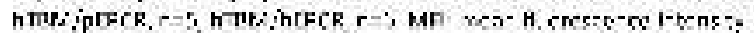

xen_12557_f3.tif 
A

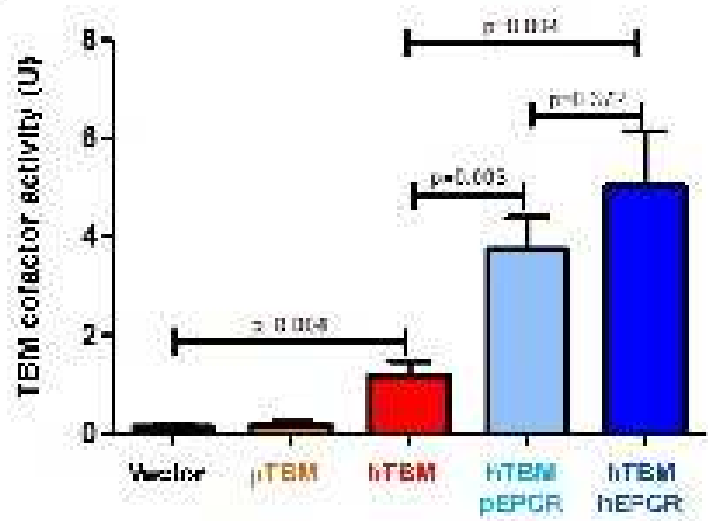

B

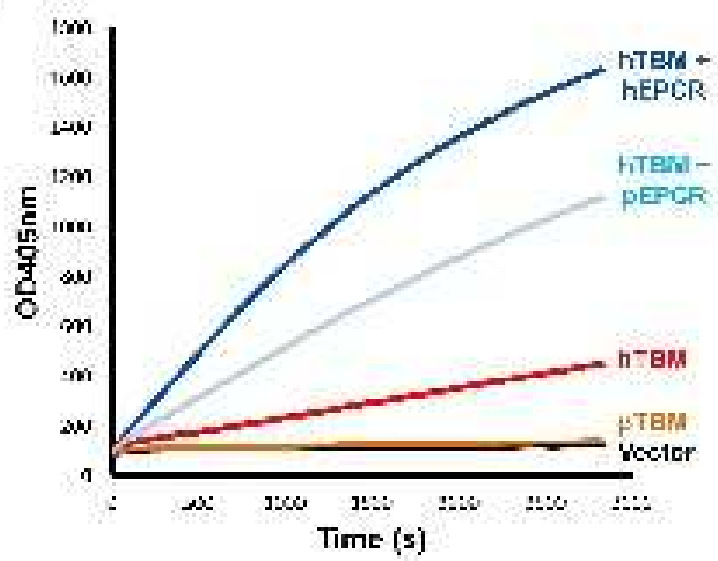

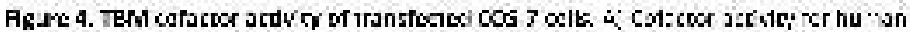

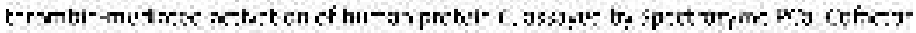

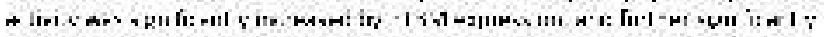

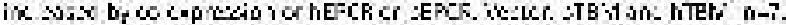

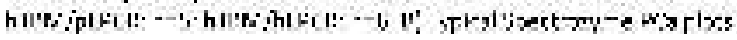

xen_12557_f4.tif 


\section{University Library}

\section{- M M N E R VA A gateway to Melbourne's research publications}

Minerva Access is the Institutional Repository of The University of Melbourne

Author/s:

Salvaris, EJ;Moran, CJ;Roussel, JC;Fisicaro, N;Robson, SC;Cowan, PJ

Title:

Pig endothelial protein $\mathrm{C}$ receptor is functionally compatible with the human protein $\mathrm{C}$ pathway

Date:

2019-09-25

\section{Citation:}

Salvaris, E. J., Moran, C. J., Roussel, J. C., Fisicaro, N., Robson, S. C. \& Cowan, P. J. (2019). Pig endothelial protein $\mathrm{C}$ receptor is functionally compatible with the human protein $\mathrm{C}$ pathway. XENOTRANSPLANTATION, 27 (2), https://doi.org/10.1111/xen.12557.

Persistent Link:

http://hdl.handle.net/11343/286439 